Paideusis

\title{
What is Existential Educational Encounter?
}

\section{Jani Koskela et Pauli Siljander}

Volume 21, numéro 2, 2014

\section{Working Compassion}

URI : https://id.erudit.org/iderudit/1071567ar

DOI : https://doi.org/10.7202/1071567ar

Aller au sommaire du numéro

Éditeur(s)

Canadian Philosophy of Education Society

ISSN

0838-4517 (imprimé)

1916-0348 (numérique)

Découvrir la revue

Citer cet article

Koskela, J. \& Siljander, P. (2014). What is Existential Educational Encounter? Paideusis, 21(2), 71-80. https://doi.org/10.7202/1071567ar

\section{Résumé de l'article}

This paper aims to clarify the meaning of the pedagogical concept of encounter by providing an overview of its use from the historical foundations of the concept in Otto Friedrich Bollnow's (1903 to 1991) philosophy to contemporary phenomenological readings by Maxine Greene, Donald Vandenberg and Robyn Harrison. The outcome is a critical analysis and evaluation of the significance of the concept in educational contexts. The aims of the paper are as follows: a) to articulate the educational significance of the concept of encounter, and b) to clarify its relationship to the humanistic concept of formation (or unfolding; Bildung), in order to establish the tension between Bildung-theory and the existential theory of human formation. The paper claims that, for a more elaborated understanding of the human educative process, the tension between the processes of encounter and Bildung should be seen as the core tension behind the holistic view of becoming human. Also, c) for an analysis of the Anglo-American reception of the concept, a phenomenological view of the encounter as a transcendental aspect of a learning process will be made in order to gain a wider view of the concept.
(C) Jani Koskela, Pauli Siljander, 2014

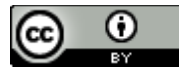

Ce document est protégé par la loi sur le droit d'auteur. L'utilisation des services d’Érudit (y compris la reproduction) est assujettie à sa politique d'utilisation que vous pouvez consulter en ligne.

https://apropos.erudit.org/fr/usagers/politique-dutilisation/ 
Paideusis, Volume 21 (2014), No. 2, pp. 71-80

\title{
What is Existential Educational Encounter?
}

\author{
JANI KOSKELA \& PAULI SILJANDER \\ University of Oulu
}

\begin{abstract}
This paper aims to clarify the meaning of the pedagogical concept of encounter by providing an overview of its use from the bistorical foundations of the concept in Otto Friedrich Bollnow's (1903 to 1991) philosophy to contemporary phenomenological readings by Maxine Greene, Donald Vandenberg and Robyn Harrison. The outcome is a critical analysis and evaluation of the significance of the concept in educational contexts. The aims of the paper are as follows: a) to articulate the educational significance of the concept of encounter, and b) to clarify its relationship to the bumanistic concept of formation (or unfolding; Bildung), in order to establish the tension between Bildung-theory and the existential theory of buman formation. The paper claims that, for a more elaborated understanding of the buman educative process, the tension between the processes of encounter and Bildung should be seen as the core tension behind the bolistic view of becoming buman. Also, c) for an analysis of the Anglo-American reception of the concept, a phenomenological view of the encounter as a transcendental aspect of a learning process will be made in order to gain a wider view of the concept.
\end{abstract}

\section{The Various Articulations of 'Encounter'}

The concept of encounter has been widely used in various educational discourses, including theoretical work in curriculum studies and intercultural education in the $20^{\text {th }}$ and $21^{\text {st }}$ centuries (c.f. Sanderson, 2004; Burke, 2003; Worley, 2004). An especially popular use of the concept in educational settings happened in the beginning of 20th century (Cantey, 1990; Deketeleare \& Klehtermans, 1996; Ramsden, 1989; Roeper, 1995; see also Rudduck, 1977). Before that, the concept had a particular sense and meaning in religious and philosophical settings, but during the turn of the century there was an appreciable change in the way encounter was seen as a part of human life: one could speak of an encounter with art or with another human being, or even with a landscape (c.f. Tschamler, 1983). An encounter between a teacher and a student would become a particularly interesting and commonly used phrase to refer to the educational reality happening both in and outside classroom situations, in both formal and informal educational settings. With the obvious ambiguity in the usage of the concept, there is also a specific sense to using such a concept in educational discourse. It does, despite having a rather bombastic sound to it, refer to and focus on a specific and relevant aspect of educational reality, which has been theoretically clarified by German educational philosopher Otto Friedrich Bollnow. He already pointed out the problems of plurality of usage, but also the new meanings the concept has gained since the days of its religious undertones in his article "Encounter and Education" (Begegnung and Bildung, 1957). In it, he paved a way to understanding encounter with its multiple articulations by stressing the existential aspects of human development, thus connecting the concept with the formation of a subject, or Bildung; a human being in process of growth from within through external influence. In this way, Bollnow was able to give a coherent and meaningful understanding of what encounter is as a fundamental part of human life in multiple situations and also give understanding of its pedagogical significance.

We will start our analysis by a systematic reading of Bollnow's existential philosophy of education in

(C) Copyright 2014. The authors, Jani Koskela \& Pauli Siljander, assign to Paideusis the right of first publication and educational and non-profit institutions a non-exclusive license to use this document for personal use and in courses of instruction provided that the article is used in full and this copyright statement is reproduced. Any other usage is probibited without the express permission of the author. 
which he articulates the concept of encounter in relation to the classical notions of formation (Bildung) established in $19^{\text {th }}$ and $20^{\text {th }}$ century German educational philosophy. We will claim that, for a more elaborated understanding of the human educative process, these discontinuous aspects of formation that Bollnow stresses in his work should be taken into account. In this article, we will articulate the educational significance of the concept of encounter, clarify its relationship to the humanistic concept of formation (or unfolding; Bildung), so as to establish the tension between Bildung-theory and the existential theory of human formation, and state in detail Bollnow's understanding of the special nature of the concept of Bildung in existential educational discourse. We will also make an analysis of the Anglo-American reception of the concept in readings by Maxine Greene, Donald Vandenberg and Robyn Harrison, who introduce a phenomenological view of encounter as a transcendental aspect of a learning process. In so doing, we aim at a wider view and a concise contemporary use of the concept. The outcome is a critical analysis of the concept but also an evaluation of its pedagogical significance.

\section{Foundations and Elaborations}

The decisive experience of encounter (in German Begegnung) evolved in Germany, particularly following the Second World War, and was linked to the feeling of shock expressed by Existentialism. The concept of encounter in education was considered before Bollnow, but less systematically. For instance, Gustav Würtenberg, in his Existen₹ und Erriebung: Aufsätze und Abhandlungen zur Pädagogik (1949), claimed that what is said about the existence of a man is also applicable to the adolescent (Vandenberg, 2002a, p. 590), a contention that indicates a clear lack of awareness of life-phases, which were later shown to be functional by Romano Guardini. The initial meaning of the term denoted an encounter with another person, often a figure from literature or history, or a figure in a work of art. Particular emphasis was placed on theological notions of an encounter with God. At the same time, a phenomenological current was apparent in philosophical anthropology, contributed by Romano Guardini in his work The Life Stages: Ethical and Educational Meaning (Die Lebensalter: Ihre Ethische und Pädagogische Bedeutung, 1959). Guardini contends that, because remembering and foresight are different in different phases of life, the mode of temporalisation and of being authentically present in the world is relative to one's life-phase (Guardini, 1959, pp. 12-13). He distinguishes between seven life-phases-pre-natal, childhood, youth, young adulthood, mature adulthood, old age, and senility-that are separated by critical turning points - birth, puberty, practical experience, experiencing the limits, retirement, and helplessness - and describes each life phase, acknowledging sub-phases such as small and large child, male and female, and so on (c.f. Guardini, 1959, p. 11). Guardini influenced the phenomenology of education by allotting value to these 'life-crises' in relation to the term authentic existence. His thinking substantially influenced Bollnow's views of the concept of encounter, which are more secular than the dialogic theologian approach.

In his formulations, Bollnow departed from the solely Christian views of dialectical theology that culminated in the work of Martin Buber, particularly in I and Thou (Ich und Du, 1977). Bollnow aimed to clarify the concept of encounter, adopting a view different from theological notions that saw encounter between man and God as an unconditionally demanding relationship (Vandenberg, 2002a, p. 90). Behind that view of the concept is a dualistic understanding of man-such as made its breakthrough in the existentialist philosophy of the 1920s - that contrasts with a humanist image of man and the classical educational ideal based on that image. Encounter was adopted in a more general sense to characterize the process by which 'I'- usually in an accidental and unexpected fashion - collide with a reality that confronts 'me' as other, alien, and resistant to 'my' natural life force (Bollnow, 1966, p. 161). In other words, encounter totally displaces a person from his or her natural course of life, and occurs without the possibility for the person to consciously affect the encounter. A displacement from normal, safe, habitable behaviour raises existential demands: one must re-evaluate one's perceptions and general conceptualizations of life. This 'secularized' version of encounter does not refer to the relationship between man and God; rather, to the relationship of a subject to what we could call otherness, to anything distinguishable from the subject. Encounter may be an encounter with a person, a work of art, a philosophy, the testimonies of religion, or even a landscape (c.f. Bollnow, 1966, p. 162). Encounter with a different entity, the other, can be harmful, potentially violent, or even disastrous. Therefore existential encounter always comes with the possibility of hazard.

As an idea, encounter is stressed in a manner we may term existential; its sense refers not to any 
particular acquaintanceship, but to an experience that shakes a person to the core. In this sense, encounter is always an existential experience. A person carried away by enthusiasm in seeking knowledge of something important to self would still not be touched deeply in an existential way (Bollnow, 1966, p. 160). On this view, it is not enough to spectate. Rather, one must engage oneself fully in the matter at hand by taking a position on it. One must decide for oneself to be either for or against the event. Bollnow aims to understand this engagement, this being-touched-by-something, by referring to it with the concept of existential encounter (c.f. Bollnow, 1966, p. 161). For Bollnow, encounter is a fundamental experience in which the subject meets something new, strange, uncontrollable, and (to the subject) incomprehensible. An encounter is a collision with everything outside one's understanding, not a meeting with the familiar. It is a meeting with something outside one's 'lifeworld'. Through this collision with something new, encounter presents a possibility for self-examination. In other words, encountering a force outside subjective understanding results in a change to that subjective understanding; one recognizes an entity that is not understood, and begins to learn. By no means is encounter necessarily a pleasant experience; it affects the subject profoundly, leading to self-examination or reflection and a change in one's way of living or being.

A significant response to questions of encounter appeared in Bollnow's Existential Philosophy and Education: A Treatise on the Discontinuous Forms of Education (Existensphilosophie und Pädagogik: Versuch über unstetige Formen der Erziehung, 1959), which furnishes a theory of discontinuous education that aims to overcome the phenomenon falling into the inauthentic, everyday existence through intermittent awakening. Bollnow recommended that, to motivate a student, instead of praise and blame, a teacher should use admonition, which by reminding students of a failure to complete helps them to reorient themselves toward fulfilling their own possibilities of being. Admonition looks forward, involves the entire temporal structure (Bollnow, 1959, p. 63), and respects the pupil's freedom because it is only a call to conscience (c.f. Bollnow, 1959, p. 66). In these terms, admonition can cause the pupil to awaken from a state of being-obligated-to-be-nothing (Nicht-so-sein-sollens) to beingobligated-to-be-oneself (Sein-sollens), and from a state of being-in-the-world (In-der-Welt-seins) to being-in-thetruth (In-der-Wabrbeit-seins) (c.f. Bollnow, 1959, pp. 47-48). This awakening may occur also in an educative encounter through the content of a curriculum such as that for which Bollnow gives a phenomenological description in 'Begegnung und Bildung, Encounter and Education' (see Bollnow, 1955b; Vandenberg, 1971, p. 158). Indeed, one may have an intellectual encounter with an author or figure of the past or present (Bollnow, 1959, p. 110; Vandenberg, 1971, p. 159), groups of people, previous times and cultures, works of poetry, and with intellectual truths (c.f. Bollnow, 1959, p. 93). To distinguish encounter from theoretical interest, Bollnow notes that deficient moods underlie abstract theorizing, and that an educative encounter involves one's whole being: "one must first of all value and only then can one understand" (c.f. Bollnow, 1959, p. 108), and, "I understand only insofar as I place myself in question" (Bollnow, 1959, p. 110). These citations precede a definition of education as "the intellectual encounter between the generations, or of the educational encounter between the rising generation and the intellectual-historical world" (Bollnow, 1959, p. 93). Teachers cannot contrive encounters with students, but they can promote their occurrence through a serious, respectful, engaged treatment of curriculum content (c.f. Bollnow, 1959, pp. 125-130).

Several problems are apparent when faced with existential formulations of pedagogy. Bollnow's 'discontinuous education' conflicts with classical notions of formation (Bildung) according to which a human being is cultivated from a human animal and its causal environment, forming a cultural buman with intentions that establish its freedoms, namely individuality, the ability to recognize self and choose for oneself. Along with this individuation one is also the subject of transmission of the culture. This process of cultivation or Bildung occurs-according to classical notions-by transmitting cultural heritage from the older generation to the new generation via education, which is regarded as a continuous, cumulative process (Bollnow, 1959, pp. 11-13; 1986, pp. 2-3). However, Bollnow's existential understanding of education prompts the statement that the development of a person can neither be continuous nor merely a cumulative process (Bollnow, 1986, pp. 4-6). Setbacks, discontinuation, lag, jumps and leaps are all a discernible part of development. Clearly, tensions exist between classical Bildung theory and existential notions of discontinuity: these tensions will be observed and clarified next. 


\section{Encounter and Education, 'Bildung'}

From the viewpoint of encounter, Bollnow sees human development as discontinuous in nature. Encounter states a tension between the subject, the 'I', and the cultural context this subject does not yet embrace. As encounter discloses things to the self and makes them thus part of its life-world, encounter seems to play a significant role in human formation, unfolding. Encounter itself is a collision; therefore human development is possible only through collisions. Bollnow states that this development of human character, namely individuation, and the tension between the individual and its culture, has been referred to from classical hermeneutics to modern pedagogy as formation, or Bildung (c.f. Benner, 1996, 2003; Spranger, 1928). Therefore to Bollnow, the concept of encounter is a very essential adjunct to the notion of Bildung. When formulating his discontinuous forms of education, Bollnow does not refer to contemporary theories of Bildung, but rather, to the classical notions of the concept (c.f. Koerrenz, 2004; Wehner, 2002).

Bollnow presents a new background philosophy for education, beginning with twofold classical notions of education. The following two basic ideas can be regarded as the foundation for all the other variants of educational thinking throughout the history of pedagogy. Bollnow terms the first idea the crafting analogy. In this analogy education is like craftsmanship in the sense that the educator moulds his material, the educatee, through an intentional, predetermined plan of action, and the result is a product of the correct and skilful use of methods. From this standpoint, education is action, and the result of the action is determined by the educator. Referring to this analogy, Bollnow cites the commonly used interpretation that ethics gives education its aims and goals, and that psychology gives education the tools and methods to achieve these goals (see Bollnow, 1966; Bräuer, 1978). The second analogy Bollnow employs when discussing education is organic growth (see Bollnow, 1966, p. 96). From this standpoint, human growth is not predetermined by outward influence, but is of inward origin, like the growth of a plant or a tree. The process of human growth is regarded as a natural phenomenon that education can at its worst only disturb. The organic growth analogy sees education as supportive action, supportive of the individual process of inward growth. This supportive action or guidance requires certain nurturing skills. Referring to these two analogies - the analogy of crafting and the analogy of organic growthBollnow also uses the terms "mechanistic" and "organic." The former is founded in the era of Enlightenment and the latter in romanticism (c.f. Benner, 1996).

Bollnow starts with a rather simple thought that, in a general sense, each life can be characterized as a process of reciprocal interaction of a living being (organism) with an environing world. And, if one extends the viewpoint to include life-history - that is, bears in mind that life does not remain the same in this interaction but conjointly enlarges and transforms itself from within in the course of time such that it grows - then one must add that this growth itself occurs in the very same way as the reciprocal interaction between the living being and the environment (Bollnow, 1959, p. 27). This means that this growth takes place in the reciprocal interaction and interpenetration of two necessarily successive, related processes: an unfolding from within, Bildung, and an assimilation from without. Unfolding, Bildung, however, can progress only so far as to how much "nourishment" it has gained from the environing world (c.f. Kümmel, 1977; Morris, 1966). Growth can continue only if it assimilates external matter. This external nourishment is the precondition for growth to occur. Bildung only succeeds and becomes actual growth as long as an individual advances toward the materiality of the outer world in which the unfolding takes place and that is to a certain degree a kind of intellectual nourishment for the growing person. However, talking of "materiality" may not be completely appropriate here: Bollnow stresses that the stimulating material should not be considered as generally available material with no relation to the concrete life processes of the individual. In actuality, it becomes nourishment only to the extent that it enters into the life-zone of this self-determining, unfolding life. It is not to be seen as something existing in the abstract, but as concrete and actual in human life world. This explains the concept of the encounter further: it is a process in which a definite actuality steps in in relation to life as one of the materials enabling its expansion, as a kind of intellectual nourishment. And thus the two concepts, Bildung and encounter, characterize the polarity in which everything comes to pass as intellectual growth. They are thus reciprocally interdependent. Encounter is not Bildung, and Bildung is not encounter. However, encounter without synchronous unfolding of human powers would stifle evolution and individual development under the mass of 
received material. Bildung without the confronting encounter would ultimately pass into emptiness (Bollnow,1955a, p. 33). This allows us to understand an important tension in the history of German educational thought. While in the Era of Enlightenment and with Johann Gottfried von Herder (1744-1803) it seemed that organic development meant nothing more than the unfolding of what was already present, the concern broadened with Wilhelm von Humboldt (1767-1835) to include the assimilation of encountered, human cultural products (c.f. Spranger, 1928; Benner, 2003). Education (Erriehung) in the full sense of the German classics can be defined from this point on as precisely this balance between assimilated materials and developed powers, with one being able to develop only in conjunction with the other. What Bollnow realises here is something significant to educational theory, and to the view of man behind it: these two processes are crucial to human development, and they are both necessary. But, they do not happen on the same life-world plane. In reality, the encounter lies on a wholly different plane and changes the whole way of thinking so radically that it cannot be added as a supplement to, or correction of a way of thinking emerging primarily from an unfolding (Bildung). Thus, these processes can never be put together: where the encounter begins, there Bildung has lost its claim, and conversely: where Bildung defines the human happening, there encounter in the full sense cannot take place (Bollnow, 1955a, p. 36). This tension of the dualism of the educative process of a human being has been lost in time in educational philosophy (c.f. Kakkori \& Huttunen, 2010).

From this understanding we move to the treatment of educative encounter, a happening where these two aforementioned processes are seen together side by side. As stated before, encounter can be described with the metaphor of two ships meeting each other at sea. These two ships do not encounter each other if they, coming from opposite directions, sail past one another. This separates encounter from other pedagogical processes, as pedagogy itself roots etymologically to "walking beside". Also, it is not an encounter if a ship encounters a stationary object. By necessity, the two who encounter are in movement. In terms of humanly encountering another human, both have their own naturally flowing everyday lives and life-worlds with their own dynamics. An encounter between those is not a meeting of the safest kind, just like an encounter between two ships at a sea is a crash course of those two ships moving in converging directions. Bollnow describes the necessary features of an educative encounter: there is always a "toward" in the encounter, it is a meeting and moreover, an impact or a collision of some sort. Encounter always includes the occurrence of actual contact. This leads to life-changing events (c.f. Kneller, 1958; Yalom, 1980; Todd, 1995; Deurzen-Smith, 1988; Jacobsen, 2008). Also, encounter would not have such a dramatic effect on the life of a human being if it were predictable (c.f. Sanderson, 2004). Therefore, Bollnow stresses that the encounter is something accidental and unpredictable. One is taken by surprise by it (Bollnow 1955a, p. 40). Educative encounter is a definitive encounter with a given subject matter, and not a collision of random things in the corner of a street. Therefore it is also appropriate to contrast the pedagogic encounter with the category of the transmittal of knowledge in instruction and the education thereby acquired. In instruction, the emphasis is solely on the "objective side," on the material to be assimilated (Bollnow, 1955a, p. 46). Pedagogical encounter does not happen on the "objective side", but is a thoroughly subjective experience. Encounter characterizes the personal meeting of the world, and this subjective experience of the fundamental difference between oneself and the world is a precondition to learning from it (c.f. Husserl, 1952; Heidegger, 1962). Thus, encounter is not about the assimilated material but about the learning subject himself, the person and his developing intellectual powers.

Encounter with an object of study, however, implies that now both sides collide with an equal weight of reality (Bollnow, 1955a, p. 47). In the encounter with an actuality that comes to meet him that does not yield before him, the person in a real sense becomes "shaken". From this fact, that encounter implies dislocation of the natural life-flow; it obtains its characteristic severity, an inexorability and inevitability. Bollnow sums up certain fundamental differences of educational encounter from educational instruction: (a) the material of education is appropriated by the subject, assimilated; it disappears in the subject, as it were, and the subject unfolds himself in this process of assimilation. One emerges enlarged and enriched; (b) the encountered thing, on the other hand, continues in its independence and consequently requires a wholly different attitude from the person, (c) the subject must answer the claim that comes to meet him in the encounter, he must answer in a suitable way, and what counts as suitable is defined not by the subject but by the encountered thing, (d) the material of education as such offers no claims, but the encountered thing steps opposite to him as a challenging thing, (e) it is a trial of the ultimate intellectual authenticity. In this "shaking up," the subject must prove himself. He can succeed or fail. 
When one speaks of education, it means the well-rounded and harmonious unfolding of human powers, Bildung. It is important for the subject to make contact with as many sides of the materials of education as possible to ensure his Bildung in all directions. Education is necessarily many-sided education (Bollnow, 1955a, p. 50). The rigor of the encounter, however, is characterized as opposite to this, for in it all harmonious development loses its meaning. Every encounter is fateful, as it immediately takes hold of the whole person. Many-sided encounters would be a contradiction in terms, for one encounter always excludes any other; the encounter is the more authentic, the more unconditionally and exclusively it takes hold of the person. Several encounters are possible only at considerable intervals from one another, never at the same time (Bollnow, 1955a, p. 50).

\section{Encounter as the Transcendental, Intrinsic Property of Learning}

What we have displayed so far about encounter reveals itself to us as something grounded in the fundamental tension between it and education as intentional action, but also between encounter and another subjective process, i.e. personal unfolding, Bildung. However, encounter has been defined further in educational theoretical contexts, which emphasize more the phenomenological aspect of the properties of encounter. Maxine Greene has exemplified transcendental phases of learning in the student's exploration of the inner and outer horizons of her life-world (Greene, 1973, p. 169, 170; Vandenberg, 2002b, p. 325). What makes transcendental phases of learning specifically transcendental is that they are aspects of the stream of consciousness that are invisible to the external, objective observer. They are irreducible to brain processes because if brain processes always caused the contents of consciousness, all we would have would be dreams and hallucinations. Fortunately, there is praxis; that is, wide-awake being in the world in which transcendental phases of learning may occur as structurations of the stream of consciousness of things, as moments of being in the world (Vandenberg, 1971, pp. 3-10; Greene, 1978, pp. 147-157).

Although the explorations of the inner and outer horizons are necessary aspects to any learning by a student with his own experiences of inner life and outer world, they are insufficient to ground the learning of the student in the world, for these horizons indicate the direction of one's spatialising attentiveness during conscious inquiry, not epistemic sub-units of a learning episode (Vandenberg, 2002b, p. 326). While pointing out the necessary role of phenomenology in educational research and discussing some existential and educational questions through phenomenological inquiry, Greene mentions what by Vandenberg (2002b) and Harrison (2000) would be called the transcendental phases of learning. These phases are (Greene, 1997, pp. 171-188): encounter, awareness, making connections, communion and enactment. Robyn Harrison (2000) articulates these phases to the fullest, not as phases of a phenomenological method but of any learning that is grounded in human being in the world. The phases formulate a distance between the dynamic of each of them and the outer horizon, or outside world as it is experienced. This distance in the learning episode is what Harrison (2000) calls "The Spatiality of Learning". This she explains further: "If knowing is a spatializing towards the world, then, this phenomenal characteristic is of fundamental importance to the way learning occurs" (Harrison, 2000, p. 95).

What is here the relevant part of these phases of learning is of course the first one being articulated, i.e. encounter. The first phase of consciously learning something - that is, becoming aware of an object, event, technique - is to encounter it, to notice its presence, and then to proceed to become aware of it more fully. This encounter can be instantaneous, happening so quickly that one passes immediately into the phase of becoming aware of it in detail, or it may occur slowly, reticently, when one simply lacks 'interest.' It can occur with a surprise and sense of wonder, and also with a feeling of awe that makes it wonderful, or perhaps without any awe, being only a matter of interest, which if sufficiently intense, becomes curiosity. The depth of wonder, interest, and curiosity propels the spatialising transcendence to the thing noticed to become more fully aware of its qualities, aspects, characteristics, properties, etc., that is, of its possibilities (Vandenberg, 2002b, p. 327).

The encounter can be a semi-conscious event, it can even be less than semi-conscious (Vandenberg, 2002b, p. 328). However, encounter is a phenomenal event of subjective consciousness. Encounter sets itself in this way as a surface between the subjective experiences of one's inner life and the outer world. Through this dynamic, however, encounter does not have to penetrate the conscious self to the fullest. Harrison (1999) says 
the phase of encounter is characterized by a sense of wakening:

The act of recognizing this encounter is a wakening responsiveness ... A wakeful encounter frees learners to project their futures and investigate their outer horizons. Freed from the world as given, the 'natural attitude,' a re-constitution of their lived world can be pursued by the learners in pedagogic dialogue with the teacher. (Harrison, 2000, pp. 61, 98)

There are degrees of intensity of the encounter that the teacher is able to invoke, ranging from the slight awareness that hardly results in a 'second look' to the encounter that generates a response like Rainer Maria Rilke's before the 'Archaean Torso of Apollo,' which seemed to say to him, 'You must change your life' (Vandenberg, 2002b, p. 330; Greene, 1967, p. 155; Bollnow, 1972, pp. 310-312; Bollnow, 1955a, p. 31; see also Field, 2006).

Vandenberg, Greene and Harrison all refer with the concept of encounter to a phenomenal state that penetrates the consciousness of a learner. Encounter in this respect is a thoroughly mental process, referring to the inner state of one's mental life and the contradiction it might have with the subjective perception of the outer world. Encounter seems to definitively address an extrinsic property of learning: it is conditionally a possible part of the mental process of learning. Why only extrinsic? An extrinsic property is a property that depends on a thing's relationship with other things (see Lewis, 1983). Vandenberg unintentionally seems to describe encounter as relational property, when describing it as a transcendental phase of learning. Although the phenomenology around the concept is concise, he refers to Johann Friedrich Herbart's four steps of instruction: clarity, association, system and method (Vandenberg, 2002b, p. 330; Herbart, 1971, p. 57) and equates these with the transcendental phases, and thus pushes encounter away from the possibility of being an essential property to learning. While doing this Vandenberg doesn't seem to stress sufficiently the difference between categories of action and categories of events or processes. Herbart's steps are instructional steps and, as such, phases of intentional educative action. This is in contradiction to the transcendental categories, as they do not directly refer to intentional action but subjective experiences of such action or even, to other mental states, i.e. learning. If by chance Vandenberg's formulation of equating instructional steps with transcendental phases would be considered correct, then the phenomenological encounter is not a necessary, intrinsic property of learning but a relational, conditional property. For Vandenberg, transcendental phases of learning are swappable with categories of instruction, and thus encounter as a transcendental phase cannot be an intrinsic property. However, in comparison to the theoretical foundations of the concept, to our understanding, Vandenberg's interpretation should be questioned in this sense. Encounter is an intrinsic property of learning: it is the first phenomenal phase of a mental process leading to awakening of the tensions and discrepancies between ones inner life-world and the outer life-world. It should not, as such, be mixed up with any instructional concepts or intentional educative action other than those which refer to them through a subjective, experiential filter. Thus encounter would still hold up to its existential foundations.

\section{Conclusion: Encounter, Learning and Unnaturalness of Human Development}

To sum up Bollnow's account of the concept of encounter, we can say that the encounter is an existential category. Only in this category, as an existential concept, is it at all intelligible. Encounter has its roots in the educational understanding of educational development(i.e. the unfolding of a person on a subjective level). Deeply moving experiences are a precondition to effecting genuinely educative assimilation. However, experience is a too much subjectively colored interpretation of what we call here encounter. If we consider the experienced thing to become wholly absorbed by the experiencing person and which we would regard only for the sake of the subjective experience, it would lose its independent significance opposite to him (see c.f. Derbolav, 1954). Instead, the concept of encounter calls special attention to the unassimilated power of actual resistance. Thus, educational encounter separates itself from mere educational instruction. Encounter is sudden, unexpected and possibly hazardous experience of a meeting with something requiring maximum intellectual powers from the subject. Only in this way can the subject gain something from the experience. The educational concept of Bildung comes close to encounter here: these concepts are to be seen close together. A 
meeting with something that "shakes a person to the core", requires all the capacity the person has to overcome this encounter, and promotes the development and unfolding of personal intellectual powers.

Greene, Vandenberg and Harrison refer to encounter as a transcendental phase of learning (Greene, 1997; Vandenberg, 2002b; Harrison, 2000). This means that encounter is not an objectively observable part of human learning, but a phenomenal and subjective aspect to this process. This definition does not stress a certain factor to a degree it would deserve. We would claim that encounter is not only an extrinsic phase to this transcendental process, but rather an intrinsic property or a necessary condition for it. No learning would occur without an individual, subjective, phenomenal encounter. But to clarify how encounter can be seen both as an extrinsic, transcendental phase and an intrinsic property of learning, the existential concept of encounter still needs to be wrested from its psychic appropriation. This means that the value of the encounter as reference to self-formation must be separated from its value as encounter in its existential sense, as first and foremost a collision with what in its essence is outside a subjective life-world, i.e. the experienced reality. But how, then, are the psychic "self-formation" and the resistance of the outer "worldliness" to be brought together?

In this paper we have reviewed two ways of referring to encounter: as a subjective experience of an educational process and as a transcendental condition to learning. Encounter in its most concise articulation has therefore two slightly different meanings. When encounter is referred to (a) as a subjective experience of educational process, which historically speaking has taken the formulation of Bildung, it is being referred to as an experience of an aspect of intentional action to which the experiencing person is part of. There is also a notion of an experience of inner unfolding, or inner growth, to which the encounter is a parallel process. When the concept of encounter is referred to (b) as a transcendental phase of learning, it is referred to as a mental state and not as an action. However, in both articulations (a) and (b), encounter is a subjective experience, i.e. a mental state. In addition, the object of this mental state can be seen in both of these meanings, (a) and (b), in two different ways: firstly, the object the encounter is referring to is action and a process set forward by this action (Learning as action, education as action) and secondly, the object of the mental state is another mental state, i.e. learning (as a mental state) or Bildung (as inner unfolding of competences). The analysis in this article shows that if we treat these two separate definitions side by side, two conclusions follow. As according to Bollnow, if encounter is not Bildung (i.e. human development as natural unfolding of inner powers), then learning is neither. If we take for granted what Vandenberg (2002b), Greene (1997) and Harrison (2000) state about encounter as a phase of learning and as such an intrinsic property, then this would be a logical conclusion. Learning has a discontinuous nature, and learning is not fully part of a natural flow of human life and development. This will bring us to concluding remarks on the meaning of the concept.

It is clear by no credible disagreement that existential encounter seems to possess a distinctively dualist nature; namely, that it seems to refer both to a phenomenon of psychic self-formation and to resistance of the world's transcendental, constitutive powers. But this separation is only formal, and not substantial to the encounter itself. There is no need to separate the subjective experiences from the materiality of the world. The world that we encounter - the strangeness intruding our experiences - is encountered in our subjective experiences. But at the same time, there are no substantive means of separating the experiencing subject from the worldly resistance being encountered. Both are constituted temporally and in a reciprocal relation. This constitution thus occurs in a manner such that no meaningful phenomenological separation can be made between the two: mind and the world. It does not make sense to speak of existential encounter merely as a mental state, nor does it make any sense to speak of an encounter with a worldly object, or "a critical mass" that is outside the bounds of experience and that would remain this way. Whatever is being encountered, is encountered as an intrusion within the range of subjective experience. This is why transcendental phase of learning in the sense of psychic, inner unfolding does not fully grasp the essence of the encounter and thus something is left out, something extrinsic to the process. What is not inherent in the psychic processes is the "world" in its phenomenological sense. At the same time, no learning would be possible without an encounter with incomprehensible resistant forces that intrude into the range of experience from the outside world. Namely, whatever is being encountered is encountered also as a thing in itself and not merely as a mental representation. But to describe this paradox, one can only rely on dualist terminology, to the "inner" realm and the outside world. The existential encounter reveals to us that there is no radical separation of the two to be made that would have any meaningful pedagogical relevance. At a first glance, encounter may not seem to play any particular role in contemporary learning theories. However, as this analysis shows, despite it having a long idea-historical 'burden' on its back (as a 
phenomenological concept), encounter is a useful theoretical tool in the contemporary formulations of human learning.

\section{References}

Benner, D. (2003). Wilhelm von Humboldts Bildungstheorie. Eine problemgeschicbtliche studie zumbBegründungszusammenhang neuzeitlicher bildungsreform. Weinheim: Juventa.

Benner, D. (1996). Allgemeine pädagogik. Weinheim/München: Juventa.

Bollnow, O. F. (1955a). Begegnung und bildung. Zeitschrift für Pädagogik, 1(1), 10-32.

Bollnow, O. F. (1955b). Neue geborgenheit. Das problem einer überwindung des existentialismus. Stuttgart: Kohlhammer.

Bollnow, O. F. (1955c). Existensphilosophie. Stuttgart: Kohlhammer.

Bollnow, O. F. (1959). Existenaphilosophie und pädagogik. Versuch über unstetige formen der erziehung. Stuttgart Berlin Köln Mainz: Kohlhammer.

Bollnow, O. F. (1966). Krise und neuer anfang. Beiträge zur pädagogischen anthropologie. Heidelberg: Quelle \& Meyer.

Bollnow, O. F. (1972). Encounter and education. (D. Vandenberg, Trans.). Educational Forum, 36, 303-312, 465472.

Bollnow, O. F. (1986). Main directions of education. Universitas, 28(4), 243-252.

Bollnow, O. F. (1988). Zwischen philosophie und pädagogik. Vorträge und aufsätże. Aachen: Norbert Friedrich Weitz Verlag.

Bräuer, G. (1978). Otto Friedrich Bollnow. In Josef Speck (Ed.), Geschichte der pädagogik des 20. Jahrbunderts (pp. 173-224). Stuttgart Berlin Köln Mainz: Verlag W. Kohlhammer.

Buber, M. (1977). Ich und Du. Heidelberg: Schneider.

Burke, D. (2003). Death and the holocaust: The challenge to learners and the need for support. Journal of Beliefs \& V alues, 24(1), 53 - 65.

Cantey, D. (1990). Ashriel Ira Mose: Encounter with an unforgettable teacher from "The Islands". Teacbing Education, 3(1), $50-55$.

Deketelaere, A. \& Kelchtermans, G. (1996). Collaborative curriculum development: An encounter of different professional knowledge systems. Teachers and Teaching, 2(1), $71-85$.

Derbolav, J. (1954). Erkenntnis und entscheidung. Wien-Stuttgart: Humboldt Verlag.

Deurzen-Smith, E. (1988). Existential counselling in practise. London: Sage.

Field, J. (2006). Lifelong learning and the new educational order. London: Trentham Books.

Guardini, R. (1959). Die Lebensalter: Ibre ethische und pädagogische Bedeutung (5th ed.) Würzburg: Wurkbund.

Greene, M. (1973). Teacher as stranger: Educational philosophy for the modern age. Belmont, CA: Wadsworth.

Greene, M. (1997). The lived world, literature, and education. In D. Vandenberg (Ed.), Phenomenology and educational discourse (pp. 169-190). Johannesburg: Heinemann.

Harrison, R.M. (2000). The spatiality of learning. (Unpublished master's thesis). The University of Queensland, Brisbane.

Heidegger, M. (1927/1962). Being and time. New York: Harper \& Row.

Herbart, J. F. (1971). Selections from Outlines of educational doctrine. (J.W. Hillesheim \& G.G. Pfister, Trans.). In J.W. Hillesheim \& G.D. Merrill (Eds.) Theory and practice in the history of Maerican education: $A$ book of readings (pp. 53-59). Pacific Palisades, CA: Goodyear.

Husserl, E. (1913/1952). The thesis of the natural standpoint and its suspension. In W.R.B. Gibson (Trans.), Ideas: General introduction to pure phenomenology (pp. 101-111). New York, NY: MacMillan.

Jacobsen, B. (2008). Invitation to existential psychology. West Sussex: John Wiley and Sons.

Kakkori, L. \& Huttunen, R. (2010). The Sartre-Heidegger controversy on humanism and the concept of man in education. Educational Philosophy and Theory, 44(4), pp. 351-365.

Kneller, G. (1958). Existentialism and wducation. New York: Wiley.

Koerrenz, R. (2004). Otto Friedrich Bollnow. Ein pädagogisches porträt. Weinheim, Basel: Beltz Verlag.

Kümmel, F. (ed.) (1977). O.F. Bollnow: Hermeneutische philosophie und pädagogik. München: Verlag Karl Alber Freiburg.

Lewis, D. (1983). Extrinsic properties. Philosophical Studies (Springer Netherlands), 44, 111-112. 
Morris, van C. (1966). Existentialism in education. New York: Harper and Row.

Ramsden, P. (1989). Perceptions of courses and approaches to studying: An encounter between paradigms. Studies in Higher Education, 14(2), 157 - 158.

Roeper, A. (1995). Reflections first encounter: A child is born, a self is born. Roeper Review, 18(2), 136 — 137.

Rudduck, J. (1977). Dissemination as the encounter of cultures. British Educational Research Journal, 3(1), 3 - 5.

Sanderson, G. (2004). Existentialism, globalisation and the cultural other. International Education Journal, 4(4), 1 20.

Spranger, E. (1928). Wilhelm von Humboldt und die bumanitätsidee. (2nd ed). Berlin: Reuther \& Reichard.

Todd, S. (1995). Psychoanalytic questions, pedagogical possibilities and authority. Review of Education, Pedagogy, and Cultural Studies, 17(1), $15-26$.

Tschamler, H. (1983). Wissenschaftstheorie. Eine einführung für pädagogen. Bad Heilbrunn: Julius Klinkhardt.

Vandenberg, D. (1971). Being and education. An essay in existential phenomenology. New Jersey: Prentice Hall.

Vandenberg, D. (2002a). Phenomenology and fundamental educational theory. In A.T. Tymieniecka, (Ed.), Phenomenology world-wide: Foundations - expanding dynamics - life-engagements. A guide for research and study. Dordrecht: Kluwer.

Vandenberg, D. (2002b). The transcendental phases of learning. Educational Philosophy and Theory, 34(3), 321-344.

Wehner, U. (2002). Pädagogik im kontext von existensphilosophie. Eine systematische untersuchung im anschuss an eberbard Krisebach, Otto Friedrich Bollnow und Theodor Ballauf. Würzburg: Königshausen \& Neumann.

Worley, V. (2004). Book review of poststructuralist readings of the pedagogical encounter. Educational Studies, $36(2), 1$.

Yalom, I. (1980). Existential psychotherapy. New York: Basic Books.

\section{About the Authors}

Pauli Siljander is a Professor of Educational Sciences at the University of Oulu. Professor Siljander's research work has focused on educational theory and philosophy, history of ideas in education, developmental trends and traditions of educational science, and conceptions of pedagogics as a discipline. Recently his research group has focused on connections between the classical theories of 'Bildung' and theories of growth based on American pragmatism. Visit the project website at: http://wwwedu.oulu.fi/bildungandgrowth. Contact info: pauli.siljander@oulu.fi

Jani Koskela is a university lecturer at the Faculty of Education at the University of Oulu, Finland, where he gained his doctorate in philosophy of education with highest distinction. His research interests are related to philosophy of education, phenomenology, university pedagogics, and educational systems. Koskela is a member of prof. Pauli Siljander's research group, funded by the Finnish Academy. Contact info: jani.koskela@oulu.fi 